\section{REFERENCES}

Cashdan, S. Visual and haptic form discrimination under conditions of successive stimulation. Journal of Experimental Psychology, 1968, 76, 215-218.

Cashdan, S., \& Zung, B. J. Effect of sensory modality and delay on form recognition. Journal of Experimental Psychology, $1970,86,458-460$.

Fico, J. M., \& Brodsky, H. S. The effect of visual and tactual stimulation on learning of abstract forms. Psychonomic Science, 1972, 27, 246-248.
Gaydos, H. F. Intersensory transfer in the discrimination of form. American Journal of Psychology, 1965, 19, 175-187.

Lobb, H. Vision versus touch in form discrimination. Canadian Journal of Psychology, 1965, 19, 175-187.

Rock, I., \& Victor, J. Vision and touch: An experimentally created conflict between the two senses. Science, 1964, 143, 594-596.

(Received for publication August 15, 1973.)

\title{
Apparent double alternation in the rat: A failure to replicate
}

\author{
SARAH PITT, STEPHEN F. DAVIS* \\ and BOBBY R. BROWN \\ Austin Peay State University, Clarksville, Tenn. 37040
}

Two groups of rats, run under odor-maximizing and odor-minimizing trial sequences, served as Ss in a three-phase study investigating the role of olfactory cues in the acquisition, extinction, and reacquisition of double-alternation patterning in the runway. The 104 acquisition trials and 8 extinction trials were run in an apparatus having hardware-cloth tops. The tops of the apparatus were covered by a transparent plastic sheet during the 32 reacquisition trials. During acquisition, double-alternation patterning failed to develop. However, significant extinction differences developed in the goal measure. During reacquisition, significant double-alternation patterning was shown by the odor-maximizing Ss. The results strongly suggest that the effective olfactory cues are airborne, and dissipate appreciably, but not completely, in the runway utilizing wire-mesh tops.

The amount of research investigating the role and nature of olfactory cues in animal maze learning has literally mushroomed in recent years. The initial report directly concerned with the possibility that rat Ss exuded discriminably different odors on reward (R) and nonreward $(\mathrm{N})$ trials would appear to be that of Ludvigson \& Sytsma (1967). This investigation showed that rat Ss were capable of learning a double-alternation pattern only under odor-maximizing conditions. A subsequent study by Seago, Ludvigson, \& Remley (1970) replicated this finding, and further indicated that anosmic Ss were incapable of learning the pattern. A study by Davis (1970), using mice as Ss, also corroberated the Ludvigson \& Sytsma (1967) data. Since the publication of the Ludvigson \& Sytsma (1967) study, research has indicated the strong possibility that odor may be an influential factor in a number of animal learning phenomena, such as latent extinction (Pratt \& Ludvigson, 1970), the depression effect (Davis \& Ludvigson, 1969), the partial reinforcement extinction effect (Prytula, Bridges, Anderson, \& Hayes, 1972; Davis, 1973; Prytula, Cox, \& Bridges, 1973), and T-maze

*Requests for reprints should be sent to Stephen F. Davis, Department of Psychology, Austin Peay State University, Clarksville, Tenn. 37040. This paper is sponsored by Robert $\mathbf{E}$ Prytula, who takes full editorial responsibility for its contents. performance (Morrison \& Ludvigson, 1970; Means, Hardy, Gabriel, \& Uphold, 1971).

If odor cues are indeed influential, and the growing body of literature would certainly indicate that they are, then some attention must be given to methods for controlling these odors. As noted in a recent article (Davis, 1973), such techniques as swabbing the apparatus with water or various chemical disinfectants, exhausting the runway air, and using anosmic Ss have been suggested and employed. It is interesting to note that the majority of the odor studies have been conducted in runways having Plexiglas lids, which serve to retain the odors in the apparatus. Recent studies reported by Phillips \& Bloom (1971) and Bloom \& Phillips (1973) have indicated that exhausting the runway air appears to be an effective odor control procedure. This would suggest the possibility that the effective odorants are airborne. At this point one might be wondering how rapidly the odor cues would dissipate in an apparatus lacking the retentive feature of the Plexiglas lid. Simply using an apparatus having wire-mesh tops, which would be more conducive to the dissipation of odors, might provide an effective and less troublesome odor control procedure. The present study, which was essentially a replication of the Ludvigson \& Sytsma (1967) study, was designed to investigate this possibility.

\section{METHOD \\ Subjects}

Fourteen naive male albino rats, purchased from the Holtzman Co., Madison, Wis., served as Ss. The Ss were approximately 120 days old at the beginning of the experiment and were housed in individual cages with water always available.

\section{Apparatus}

The apparatus consisted of a single straight runway $(11.43 \mathrm{~cm}$ wide, $12.70 \mathrm{~cm}$ high). A $28.10-\mathrm{cm}$ gray startbox was separated from a 91.44-cm black run section by a Masonite guillotine door. A second guillotine door separated the run section from a $30.48-\mathrm{cm}$ black goalbox. Raising the start door activated a Standard Electric Timer (start time). Passing through a photoelectric beam located $15.24 \mathrm{~cm}$ beyond the start door stopped the first timer and activated a second timer (run time). Breaking a second beam, located $76.20 \mathrm{~cm}$ beyond the first beam, stopped the second timer and started a third timer (goal time). Breaking a third beam, located $5.08 \mathrm{~cm}$ in front of the goal cup, stopped the third timer. The plastic goal cup, recessed into the back wall of the goalbox, was $4 \mathrm{~cm}$ high, $4 \mathrm{~cm}$ wide, and 
Table 1

Schedules for the Daily Administration of $R$ and $N$ Trials

\begin{tabular}{|c|c|c|c|c|c|c|c|c|}
\hline \multirow[b]{2}{*}{$S$} & \multicolumn{8}{|c|}{ Trial } \\
\hline & 1 & 2 & 3 & 4 & 5 & 6 & 7 & 8 \\
\hline \multicolumn{9}{|c|}{ Group P } \\
\hline 1 & R1 & $\mathbf{R} 2$ & N1 & $\mathrm{N} 2$ & R1 & $\mathbf{R} 2$ & N1 & $\mathrm{N} 2$ \\
\hline 2 & $\mathbf{R}$ & $\mathbf{R}$ & $\mathbf{N}$ & $\mathrm{N}$ & $\mathbf{R}$ & $\mathbf{R}$ & $\mathbf{N}$ & $\mathbf{N}$ \\
\hline 3 & $\mathbf{R}$ & $\mathbf{R}$ & $\mathrm{N}$ & $\mathrm{N}$ & $\mathbf{R}$ & $\mathbf{R}$ & $\mathbf{N}$ & $\mathbf{N}$ \\
\hline 4 & $\mathrm{R}$ & $\mathbf{R}$ & $\mathrm{N}$ & $\mathrm{N}$ & $\mathbf{R}$ & $\mathbf{R}$ & $\mathrm{N}$ & $\mathbf{N}$ \\
\hline 5 & $\mathbf{R}$ & $\mathbf{R}$ & $\mathbf{N}$ & $\mathrm{N}$ & $\mathrm{R}$ & $\mathbf{R}$ & $\mathbf{N}$ & $\mathbf{N}$ \\
\hline 6 & $\mathbf{R}$ & $\mathbf{R}$ & $\mathbf{N}$ & $\mathbf{N}$ & $\mathbf{R}$ & $\mathbf{R}$ & $\mathbf{N}$ & $\mathbf{N}$ \\
\hline 7 & $\mathbf{R}$ & $\mathbf{R}$ & $\mathrm{N}$ & $\mathrm{N}$ & $\mathbf{R}$ & $\mathbf{R}$ & $\mathrm{N}$ & $\mathbf{N}$ \\
\hline \multicolumn{9}{|c|}{ Group NP } \\
\hline 1 & R1 & R2 & $\mathrm{N} 1$ & $\mathrm{~N} 2$ & $\mathrm{R} 1$. & $\mathrm{R} 2$ & $\mathrm{~N} 1$ & $\mathrm{~N} 2$ \\
\hline 2 & $\mathbf{R}$ & N1 & N2 & R1 & R2 ${ }^{\circ}$ & N1 & N2 & $\mathbf{R}$ \\
\hline 3 & N1 & N2 & R1 & R2 & N1 & N2 & R1 & R2 \\
\hline 4 & $\mathbf{N}$ & R1 & R2 & N1 & N2 & R1 & R2 & $\mathbf{N}$ \\
\hline 5 & R1 & $\mathrm{R} 2$ & N1 & N2 & R1 & $\mathrm{R} 2$ & N1 & N2 \\
\hline 6 & $\mathbf{R}$ & N1 & N2 & R1 & R2 & N1 & N2 & $\mathbf{R}$ \\
\hline 7 & N1 & N2 & R1 & R2 & N1 & N2 & R1 & $\mathbf{R} 2$ \\
\hline
\end{tabular}

Note-Trials 1 and 8 for Ss 2, 4, and 6 in Group NP were excluded from the data.

$3.40 \mathrm{~cm}$ deep. Hardware-cloth tops covered the entire apparatus.

\section{Procedure}

On Day 1 of the experiment, all Ss were placed on a food-deprivation schedule; they were maintained at $85 \%$ ad lib body weight for the duration of the experiment. All Ss were fed at the completion of the experiment.

A 4-day pretraining phase immediately preceded the experiment proper. On the first 2 days of pretraining, each $S$ was handled and gentled for $2 \mathrm{~min}$. Each $\mathrm{S}$ received $5 \mathrm{~min}$ of free exploration in the apparatus on the last 2 days of pretraining. During these exploration trials, all photoelectric equipment was operative, doors were raised, and no food was present. All Ss received pellet habituation on each of the 4 days of pretraining. Pellet habituation consisted of each S's receiving $1045-\mathrm{mg}$ pellets in the home cage prior to being fed the daily ration.

Before the beginning of pretraining, the Ss were assigned randomly to one of two groups (P or NP). Also, each S was assigned randomly a permanent ordinal position within his respective group. All trials were given in this order during the experiment (i.e., S 1 was always run first, and preceded S 2, who preceded S 3 , etc.). All Ss within a group received a given trial before the next trial was administered. Group $P$ alternated daily with Group NP in being run first. All trials were administered to the first group before the second group was run. Group P differed from Group NP with respect to the daily within-trial R-N sequence. For Group P, the within-trial R-N sequence was homogeneous (odor-maximizing conditions), whereas for Group NP the within-trial R-N sequence was heterogeneous (odor-minimizing conditions).

The experiment proper was divided into three phases: acquisition, extinction, and Acquisition II. The acquisition phase consisted of 104 trials ( $52 \mathrm{R}$ and $52 \mathrm{~N}$ trials), administered in a double-alternation sequence at the rate of $8 /$ day. The schedule for the daily administration of acquisition trials to Groups $P$ and NP was identical to that employed by Ludvigson \& Sytsma (1967), and is reproduced in Table 1. Reward consisted of 15 45-mg Noyes pellets. On nonreward trials, $S$ was confined to the empty goalbox for $20 \mathrm{sec}$. One day of extinction (8 trials) immediately followed the 104 acquisition trials.

A 4-day (32-trial) reacquisition phase (Acquisition II) immediately followed extinction. During this phase, the tops of tha apparatus were covered by a thin, transparent plastic sheet to prevent odor cues from dissipating. Other than this modification to the apparatus, the conditions during Acquisition II were identical to those of the initial acquisition phase.

During all phases of the experiment, the entire apparatus was swabbed with a damp sponge before the running of $S 1$ in both groups. The inter-S interval was approximately $12-15 \mathrm{sec}$ during all phases of the experiment.

\section{RESULTS}

Group 1 mean goal speeds (meters/sec) over the 13 days of acquisition and one day of extinction are presented in Fig. 1. As can be seen from Fig. 1, the performance of both groups improved over the course of acquisition. However, differential R-N responding failed to develop. The start and run measures presented similar findings. Analysis of variance confirmed the graphical impressions by indicating that only the trial blocks factor was significant (start, $F=232.98$, df $=6 / 130$, $\mathrm{p}<.01$; run, $\mathrm{F}=154.16, \mathrm{df}=6 / 130, \mathrm{p}<.01$; and goal, $\mathrm{F}=59.08, \mathrm{df}=6 / 130, \mathrm{p}<.01)$. Analysis of variance performed for the speed data for all three measures for the extinction phase indicated that there were no significant effects in the start and run measures. However, a significant trials $(F=51.57, \mathrm{df}=7 / 70$, $\mathrm{p}<.01)$ and a significant Groups by Trials interaction $(F=12.41, \mathrm{df}=7 / 70, \mathrm{p}<.01)$ were found in the goal measure analysis. The significant Groups by Trials interaction was further investigated through the use of simple main effects analysis. The results of these

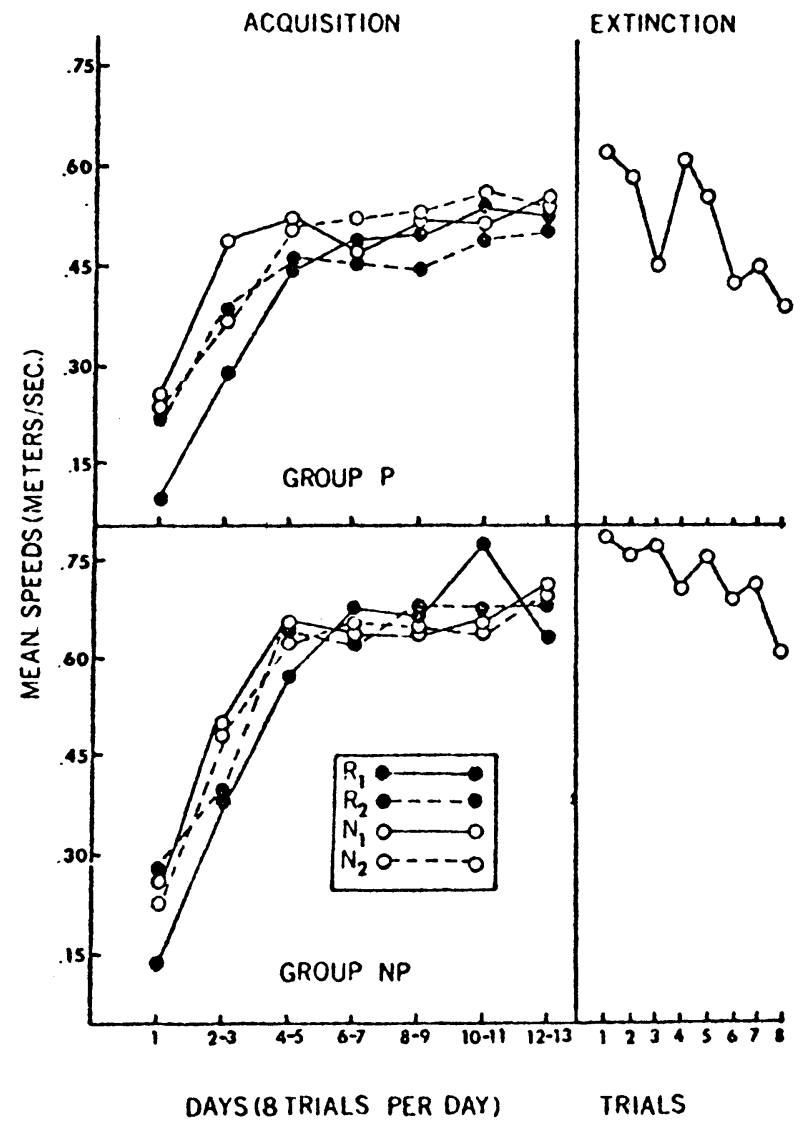

Fig. 1. Mean goal speeds (meters/sec) during acquisition and extinction. 
analyses indicated that Group $\mathbf{P}$ was approaching the goal significantly more slowly than Group NP on Trial 3 $(\mathrm{F}=7.77, \mathrm{df}=1 / 10, \mathrm{p}<.05)$ and Trial $6(\mathrm{~F}=5.02, \mathrm{df}=$ $1 / 10, \mathrm{p}<.05)$.

Figure 2 shows the mean goal speeds (meters/sec) during the second acquisition phase. Analysis of variance was performed on the speed data for the last 2 days of this phase (the point at which recovery from extinction had essentially been completed). This analysis indicated that the groups factor $(F=5.27, \mathrm{df}=1 / 10, \mathrm{p}<.05)$ and the $R$ vs $N$ factor $(F=7.32$, $d f=1 / 30, p<.01)$ were significant. The significant $R$ vs $N$ effect was further investigated through the use of the Newman-Keuls procedure, which indicated that Group P was approaching the goal significantly $(\mathrm{p}<.01)$ more slowly on $\mathrm{N}$ trials. Analyses of the start and run data for Acquisition II yielded no significant effects.

\section{DISCUSSION}

The present study does not tend to negate the significance of odor cues as determinants of responding in runway studies. It suggests, however, that in the runway situation using wire-mesh tops there are cues present which are potentially strong enough to alter behavior. More specifically, the data of the present study indicates the possibility that odor cues were present during the acquisition phase (i.e., some conditioning had taken place for Group P), but their effects were not felt until the later extinction phase. The addition of the plastic covering during Acquisition II, and the significant patterning shown by Group $\mathbf{P}$

\section{ACQUISITION 11}

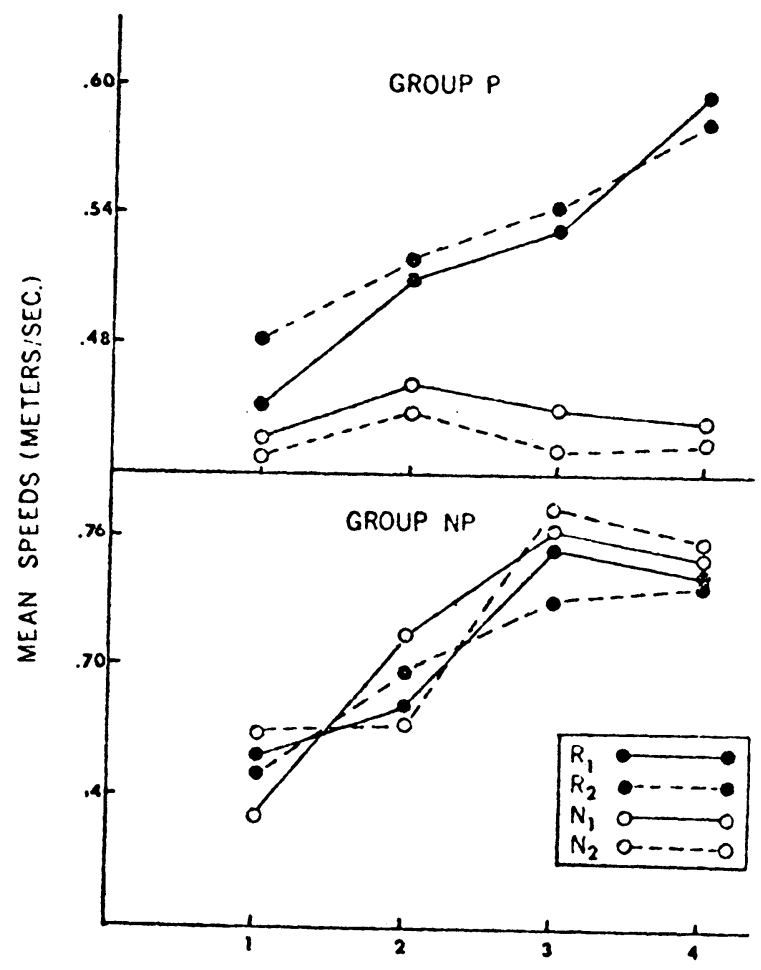

DAYS (8 TRIALS PER DAY) during this phase, once again demonstrated the powerful influence that odor cues can have on responding. Taken as a whole, the results of the present study are supportive of the view that the effective odorants are primarily airborne and may dissipate appreciably unless solid, odor-retaining lids are employed.

Obviously, these results and those of other odor studies pose a problem for studies not employing odor controls. In order to further minimize the effects of this variable, methods of odor control need to be implemented. Bloom \& Phillips (1973) appear to have successfully created a situation in which odor cues were apparently completely eliminated. These investigators employed a fan to exhaust the runway air prior to the running of each $S$ in one group. For a second group the air was not exhausted. Double-alternation patterning was displayed by th: Ss run under the nonexhaust conditions, but not for Ss run under the exhaust conditions. In a second phase, the exhaust conditions were reversed for half of the $S s$ in each group. The results of the second phase indicated that the double-alternation patterning was eliminated for the Ss shifted from nonexhaust to exhaust. Possibly more important for the points raised above, no patterning developed during the second phase (16 trials) for the Ss shifted from exhaust to nonexhaust conditions. This would indicate that no conditioning had occurred during the first phase under the exhaust conditions. The present study and the one reported by Bloom \& Phillips (1973) are similar in one additional respect. During the initial phase of the Bloom \& Phillips (1973) study, it was reported that Ss run under nonexhaust (odor-maximizing conditions), in addition to displaying significant double-alternation patterning, ran more slowly than the exhaust-condition Ss on $\mathrm{R}$ trials. As can be seen from Fig. 2, similar results occurred during Acquisition II of the present study. Thus, it would appear that when a discriminable cue is made available, and attended to by $S$, instrumental performance may be effected.

\section{REFERENCES}

Bloom, J. M., \& Phillips, J. M. Conspecific odors as discriminative stimuli in the rat. Behavioral Biology, 1973, 8, 279-283.

Davis, S. F. Conspecific odors as cues for runway behavior in mice. Psychonomic Science, 1970, 19, 169-170.

Davis, S. F. Heterogeneous squad composition, odor cues, and the partial reinforcement effect. Perceptual \& Motor Skills, $1973,36,1163-1169$

Davis, S. F., \& Ludvigson, H. W. The "depression effect" and the problem of odor control. Psychonomic Science, 1969, 14, 193-194.

Ludvigson, H. W., \& Sytsma, D. The sweet smell of success: A pparent double alternation in the rat. Psychonomic Science, $1967,9,283-284$

Means, L. W., Hardy, W. T., Gabriel, M., \& Uphold, J. D. Utilization of odor trials by rats in maze learning. Journal of Comparative \& Physiological Psychology, 1971, 76, 160-164.

Morrison, R. R., \& Ludvigson, H. W. Discrimination by rats of conspecific odors of reward and nonreward. Science, 1970, 167, 904-905

Phillips, J. M., \& Bloom, J. M. Control of conspecific odors in the runway. Psy chological Reports, 1971, 29, 838.

Pratt, L. K., \& Ludvigson, $H$. W. The role of odor in latent extinction. Psychonomic Science, 1970, 20, 189-190.

Prytula, R. E., Bridges, C. C., Anderson, H. R., \& Hayes, L. C. Partial reinforcement under odor control. Psychological Reports, 1972, 30, 215-221.

Prytula, R. E., Cox, T. P., \& Bridges, C. C. Acquisition and extinction of a runway response as a function of between- or within-subjects odor condition. Psychological Reports, 1973, 32, 367-373.

Seago, J. D., Ludvigson, H. W., \& Remley, N. R. Effects of anosmia on apparent double alternation in the rat. Journal of Comparative \& Physiological Psychology, 1970, 71, 435-442.

\section{NOTE}

1. $\mathrm{S} 1$ in each group was omitted.

Fig. 2. Mean goal speeds during Acquisition II. 